\title{
KETERKAITAN AKTIVITAS PRADAKSINA PADA RAGAM TIPOLOGI BANGUNAN STUPA
}

\author{
Ferlina Sugata \\ (Email: ferlina_sugata@yahoo.com) \\ Program Studi Desain Interior \\ Fakultas Seni Rupa dan Desain \\ Universitas Kristen Maranatha \\ JI. Prof. Drg. Surya Sumantri No 65, Bandung, Indonesia
}

\begin{abstract}
ABSTRAK
Pradaksina, sebagai salah satu aktivitas puja bakti dalam agama Buddha, adalah sikap untuk mempersiapkan batin dengan cara berjalan berkeliling searah jarum jam dari Timur ke Barat sebanyak tiga kali. Dalam pelaksanaannya, ada dua macam aktivitas pradaksina berdasarkan aliran dalam agama Buddha, yaitu menurut tradisi Theravada yang mengutamakan makna penghormatan dan tradisi Mahayana yang mengutamakan makna meditasi.Bangunan stupa sebagai salah satu sarana puja bakti dalam agama Buddha merupakan wadah untuk menampung aktivitas puja bakti, dalam konteks ini adalah pradaksina. Selain sebagai wadah untuk menampung aktivitas, stupa juga berfungsi sebagi objek penghormatan itu sendiri dalam pelaksanaan puja bakti. Pada dasarnya, stupa adalah monumen yang didirikan untuk menyimpan relik atau abu dari seorang suci setelah beliau meninggal dan dikremasi. Pada perkembangan selanjutnya, stupa sebagai arsitektur religius agama Buddha awal, menjadi pengganti image Buddha Parinibbana yang kemudian merebak ke seluruh dunia dengan bentuk arsitektur awal sebagai komposisi dari jubah, mangkuk, dan tongkat Sang Buddha.Keterkaitan antara kedua hal tersebut di atas, antara pradaksina sebagai aktivitas yang ditampung pada fungsi bangunan stupa, ternyata saling mempengaruhi terhadap perwujudan aktivitas pada wadahnya diantaranya dalam hal menentukan dimensi ruang yang terbentuk, mempertegas kualitas ruang yang terbentuk, menjadikan bentuk dan massa arsitektural sebagai orientasi dari ruang yang terbentuk, serta menjadikan stupa sebagai wadah arsitektur, bukan massa skulptural. Namun adanya keterkaitan tersebut hanya berupa dampak secara spasial dan bukanlah merupakan perubahan secara hakiki akan makna spiritual yang terkandung pada pradaksina dan bangunan stupa sebagai ekspresi religius. Jadi tidak ada pergeseran makna yang terjadi pada keduanya.
\end{abstract}

Kata Kunci : keterkaitan; pradaksina; tipologi bangunan stupa

\section{ABSTRACT}

Circumambulation as one of the Buddhist worship activity is a pathway around the shrines clockwise, from East to the West. There are two kinds of pradaksina activity refer to schools in Buddhism, the Theravada as an honor symbol and the Mahayana as one type of meditation. Stupa as one of Buddhist worship architecture is a place to accommodate the activity itself and the worship symbol as well. Stupa is a conical monument erected over relics of the Buddhas, Arhats, Kings or other great men. Stupa as a religious architecture nowadays became the image of The Buddha as known all around the world which is also known as the symbol of the composition of robe, bowl, and walking stick from a monk. The interrelatedness between the pradaksina as an activity and the stupa as the architecture cause some effects that related to space dimension, space quality, orientation of space, and function of the building. All the effects only influence the spatial matter but not influence the meaning of pradaksina and the stupa.

Keyword: pradaksina; stupa's typology; the interrelatedness 


\section{PENDAHULUAN}

Kedudukan arsitektur sebagai ilmu terapan sudah tentu mengadopsi berbagai disiplin cabang-cabang ilmu lain untuk menopang keberadaan arsitektur. Hal ini juga berpengaruh secara langsung atau tidak langsung terhadap produk arsitektur yang dihasilkan. Adanya berbagai disiplin ilmu tersebut pasti mempengaruhi terciptanya suatu produk arsitektur, diantaranya termasuk bidang religi.

Banyaknya faktor yang mempengaruhi proses berarsitektur dan pertimbanganpertimbangan yang seringkali membingungkan dalam mengambil suatu keputusan dalam proses desain membuktikan pula bahwa arsitektur dipengaruhi oleh banyak hal berdasarkan ragamnya disiplin ilmu yang menjadi elemen ilmu arsitektur. Sebaliknya, arsitektur juga dapat mempengaruhi disiplin ilmu yang lainnya. Kajian tentang fungsi, bentuk, iklim, sirkulasi, utilitas, dan lain-lain merupakan beberapa faktor dari banyak faktor yang perlu dipertimbangkan dalam berarsitektur. Faktor-faktor lain seperti ekonomi, budaya, sosial, dan lain-lain merupakan faktor yang juga menjadi pertimbangan. Begitu pula dengan faktor religi. Mengingat pada awalnya arsitektur ditujukan untuk pelangsungan hidup secara kosmis dan bukan untuk sekedar penikmatan rasa estetika bangunan, maka faktor religi sebagai acuan kehidupan kosmis manusia menjadi pemicu awal lahirnya arsitektur religius.

Setara dengan faktor-faktor pertimbangan tersebut di atas, dalam berarsitektur, faktor religi memiliki peranan tertentu dalam proses desain guna menghasilkan suatu produk arsitektur. Hal ini dinyatakan juga oleh Charles Jencks mengenai definisi arsitektur sebagai makna yang dibentuk dan merupakan ekspresi dari siapa kita sesungguhnya. Apalagi jika objek yang dikaji adalah produk arsitektur yang bernafaskan religius yang notabene mengandung fenomena dan makna tertentu dalam wujud fisik dan proses dalam menghasilkannya produk tersebut.

Di sisi lain, aktivitas sebagai pergerakan yang menjadi citra dari ruang fisik spasial yang diwadahi oleh produk arsitektur, menghasilkan suatu pengalaman spasial tertentu. Kedua komponen dalam arsitektur ini, baik aktivitas maupun wadahnya, pada dasarnya memiliki makna dan fenomena masing-masing jika ditinjau dari sejarah lahirnya. Pada akhirnya, kedua hal diatas saling berhubungan kemudian cenderung melahirkan fenomena baru. Sebuah fenomena merupakan objek abstrak. Namun di lain pihak, produk arsitektur yang 
dihasilkan merupakan objek riil berupa tatanan fisik, baik itu fisik material maupun fisik spasial. Begitu pula dengan aktivitas yang nyata dilakukan, dapat diamati, dan dirasakan. Melalui kedua komponen yang nyata inilah, penulis mencoba mengungkapkan fenomena masing-masing dan keterkaitannya satu sama lain.

\section{METODE PENELITIAN}

Metode kualitatif adalah suatu cara untuk melihat suatu fenomena. Dalam bidang arsitektur, untuk memperoleh data kualitatif tersebut dalam hal ini adalah melalui fenomena yang dapat dilakukan melalui berbagai pendekatan, salah satunya adalah dengan objek riil berupa produk arsitektur itu sendiri, dan aktivitas yang terjadi pada produk arsitektur tersebut. Dengan demikian, fenomena dapat diobservasi melalui cara-cara pengamatan dan penghayatan langsung.

Bangunan bernafaskan religius merupakan suatu produk arsitektur yang pada umumnya mengandung suatu fenomena tertentu.Oleh sebab itu, dalam mengungkap data kualitatif dari objek studi berupa bangunan religi diperlukan pendekatan lebih dulu mengkaji fisik material, baru kemudian fisik spasial. Demikian pula halnya dengan bangunan religi penganut agama Buddha yang juga mengandung suatu fenomena tertentu dibalik wujud fisik arsitekturnya yang menampung aktivitas religius, mengingat objek studi berupa kajian dari salah satu produk historis yang muncul pada saat agama Buddha berkembang di India sekitar 588 SM dan terus berkembang sampai dengan saat ini di Indonesia, sehingga wujud fisiknya masih nyata, dapat diobservasi, terlepas dari isu bahwa adanya pergeseran makna atau tidak.

Arsitektur sebagai salah satu sarana puja bakti dalam agama Buddha memiliki peranan cukup penting dalam melakukan aktivitas puja bakti, ruang sebagai wadah dari pergerakan aktivitas merupakan suatu kebutuhan. Sebaliknya aktivitas puja bakti pun membutuhkan sarana arsitektur sebagai objek puja bakti, selain sekedar wadah aktivitas. Dengan kata lain, produk arsitektur pun menjadi suatu kebutuhan dalam menjalankan praktek spiritual dalam kehidupan beragama seiiring dengan semakin maraknya perkembangan sisi spiritual sebagai kebutuhan hidup manusia.

Ada bermacam-macam bangunan yang bernafaskan religius bagi umat Buddha.Salah satunya adalah bangunan sebagai sarana puja bakti bagi para umat Buddha.Puja bakti 
adalah salah satu bentuk penghormatan dalam keyakinan agama Buddha. Untuk menampung aktivitas-aktivitas dalam melaksanakan puja bakti tersebut di atas, dibutuhkan suatu sarana puja bakti berupa bangunan sebagai tempat untuk menampung semua aktivitas tersebut.

Bangunan puja bakti ini masih dapat dibeda-bedakan lagi menurut fungsinya dan skala besaran bangunannya. Bangunan puja bakti yang dikaji sebagai objek studi adalah bangunan puja bakti yang berupa bangunan stupa. Pembatasan ini didasarkan pada perkembangan arsitektur religius, khususnya arsitektur stupa yang mengalami berbagai modifikasi dengan wujud fisik dan bentuk yang serumpun, sehingga stupa sebagai bangunan yang lebih orisinal inilah yang akan dikaji pada penelitian ini.

Aktivitas puja bakti dalam agama Buddha yang beraneka ragam baik secara makna maupun pergerakannya, kurang memfokuskan objek studi, mengingat pradaksina dan bangunan stupa memiliki keterkaitan langsung terhadap Buddha, maka untuk lebih memfokuskan studi ini, aktivitas pradaksina ini yang kemudian dikaji lebih lanjut.

Pradaksina merupakan salah satu aktivitas puja bakti yang dalam agama Buddha dapat dilakukan pada sarana lain selain bangunan stupa. Namun, hal ini tentu saja juga memiliki makna yang berbeda, secara khusus lebih mengacu pada tradisi yang ada, yaitu Theravada dan Mahayana.Korelasi yang terjadi antara keduanya dengan perbedaan latar belakang dan makna inilah yang menimbulkan rasa keingintahuanPenulis terkait peranan masing-masing yang pada akhirnya dapat menimbulkan pengaruh-pengaruh tertentu bagi keduanya.

Secara lebih rinci, bangunan yang diambil sebagai objek studi yaitu bangunan stupa dengan bentuk yang tidak mengalami transformasi bentuk yang krusial,karena pada perkembangan selanjutnya akibat pengaruh budaya, arsitektur dan seni, bentuk stupa ini dapat menjadi bentuk pagoda yang marak lahir di negara Cina.

\section{PEMBAHASAN}

\section{Pradaksinasebagai Salah satu Aktivitas Puja Bakti dalam Agama Buddha}

Kebaktian atau puja bakti di dalam agama Buddha merupakan salah satu perwujudan ajaran Sang Buddha tentang keyakinan. Hal ini merupakan faktor penting dalam indriya samata yang dibutuhkan untuk tujuan akhir dari agama Buddha, yaitu mencapai 
pembebasan. Keyakinan yang dimaksudkan disini bukanlah suatu kepercayaan yang membuta. Keyakinan tersebut diperoleh karena adanya pengertian benar yang dimiliki oleh umat akan ajaran Sang Buddha.

Pada masa The Primitive Buddhism, Sang Buddha tidak pernah mengajarkan kepada muridmurid beliau tentang puja bakti melainkan mengajarkan ajaran Dharma agar semua mahluk terbebas dari penderitaan. Sang Buddha sendiri menolak untuk dipuja atau dijadikan objek puja bakti. Namun beliau mengajarkan bahwa menghormat mereka yang patut dihormati adalah berkah termulia.

Dalam sebuah kutipan ajaran Sang Buddha diatas, dalam Maha Manggala Sutta, dikatakan bahwa menghormat yang patut dihormati merupakan anjuran Sang Buddha sebagai dasar untuk kemajuan batin individu serta kelompok individu. Orang yang tidak dapat menghormati orang yang patut dihormati tidak akan dapat memperoleh kemajuan batin karena keterbatasan keadaan batinnya pada saat itu. Orang yang seakan-akan buta sehingga tidak dapat melihat atau mengenali sesuatu yang lebih tinggi atau lebih baik dari kolam lumpur atau tempurung sebagai penutup dirinya, maka perkembangan batinnya akan terhambat. Dengan menghormati serta menghargai orang lain, seseorang dapat menghargai kemampuan batinnya sendiri.

Sebelum Sang Buddha mangkat pada tahun 543 SM, tidak ada satu pun bentuk puja bakti yang dilakukan oleh para penganut Buddha sebagai bentuk penghormatan. Adapun bentuk penghormatan yang dilakukan oleh para pengikut beliau pada zaman tersebut berupa pelayanan kepada beliau secara langsung yang disebut vattha, yang diwujudkan dengan cara merawat Sang Buddha, membersihkan ruangan, mengisi air, dan lain-lain.

Setiap bulannya pada hari bulan gelap dan bulan purnama atau tanggal 1 dan 15 menurut penanggalan kalender lunar, para bhikkhu dan umat berkumpul untuk mendengarkan khotbah Sang Buddha. Namun setelah Sang Buddha mangkat, para bhikkhu dan umat tetap berkumpul, maka siapa yang akan dilayani dan akan memberikan khotbah untuk didengarkan oleh para bhikkhu dan umat?

Bentuk-bentuk puja bakti muncul setelah masa The Primitive Buddhism berakhir, saat Sang Buddha mangkat, para murid beliau bingung mencari cara untuk menghormat kepada guru mereka. Oleh sebab itu muncullah tata cara kebaktian yang dipergunakan sampai saat 
sekarang sebagai wujud penghormatan umat Buddha kepada Sang Buddha, dan juga sebagai pengganti kebiasaan vattha tadi. Esensi dari puja bakti tersebut adalah bukan penghormatan akan bentuk jasmani Sang Buddha sendiri, namun terhadap Dharma mulia beliau.

Ada dua macam puja bakti dalam agama Buddha, yaitu:

\section{Amisa Puja}

Yaitu puja bakti yang dilakukan untuk menghormat dengan cara memuja yang patut dipuja dengan medium materi persembahan seperti lilin, dupa, dan lain-lain.

\section{Patipati Puja}

Yaitu puja bakti yang dilakukan untuk menghormat dengan melaksanakan ajaran, mempraktikkan ajaran.Patipati Puja merupakan cara menghormat yang tertinggi kepada Sang Buddha.

Puja bakti dapat dilakukan secara perorangan maupun kelompok. Baik secara perorangan maupun kelompok, dalam melaksanakan puja, ada beberapa sikap batin yang dilakukan untuk mempersiapkan batin untuk dipusatkan pada objek dalam puja bakti, yaitu:

1. Sikap Anjali

Merupakan sikap merapatkan kedua belah telapak tangan di depan dada dalam posisi duduk, bersujud, berdiri, maupun berjalan .

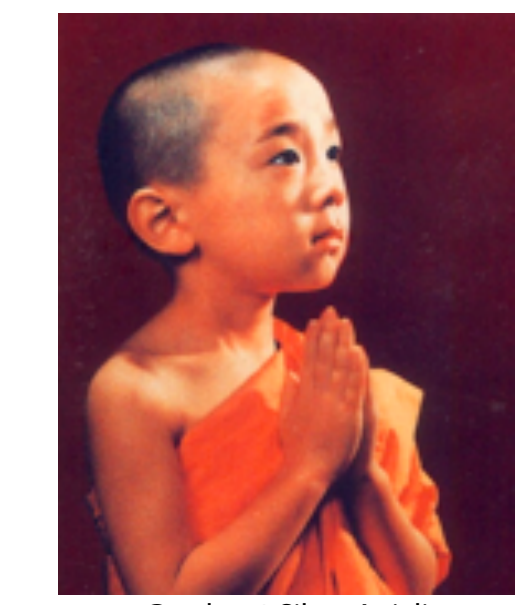

Gambar 1.Sikap Anjali

Sumber: Sejuta Pelita Sejuta Harapan, 2005

\section{Sikap Namaskara}

Merupakan sikap bertumpu lutut menghormat dengan cara membungkuk dengan lima titik utama menumpu pada tanah atau lantai. 


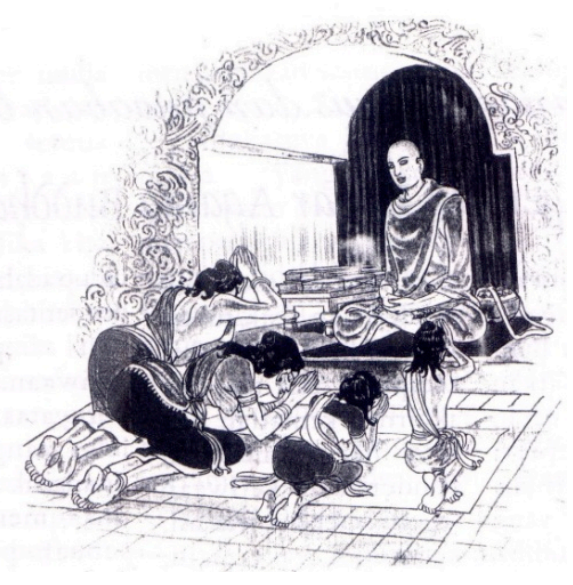

Gambar 2.Sikap Namaskara

Sumber: Majalah Buddhis Indonesia, Edisi ke-35, Juni, 1995

\section{Sikap Pradaksina}

Berjalan berkeliling dari kiri ke kanan searah jarum jam sebanyak tiga kali terhadap suatu objek.

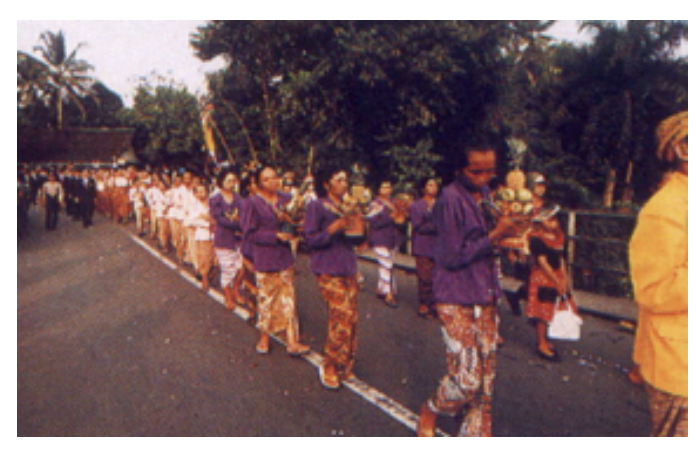

Gambar 3.Sikap Pradaksina

Sumber: Makna Candi Bharabudur-Mendut, Majalah Buddhis Indonesia, Edisi ke-34, Mei 1995

Padakkhina dalam Bahasa Pali atau pradaksina dalam Bahasa Sansekerta atau biasa juga disebut prosesi dalam Bahasa Indonesia, merupakan salah satu aktivitas puja bakti yang terdapat di dalam agama Buddha. Pradaksina adalah suatu sikap mempersiapkan batin dalam melakukan puja bakti dengan cara berjalan berkeliling, dari kiri ke kanan, dari Timur ke Barat, searah jarum jam sebanyak tiga kali.

Wadah tempat menampung aktivitas pradaksina, pada awalnya berupa ruang terbuka, tempat pelaku aktivitas mengelilingi objek berupa orang yang dihormati. Ada pula yang melaksanakan pradaksina dengan berkeliling pada sebuah pohon. Berkembangnya 
arsitektur di India, khususnya arsitektur religius agama Buddha, muncul pula beberapa bangunan yang dapat menampung aktivitas pradaksina. Adapun wujud arsitektur yang merupakan wadah pradaksina tersebut adalah berupa stupa, vihara, maupun cetiya.

\section{Asal Mula Pradaksina}

Pada mulanya, di masa Sang Buddha masih menyebarkan Dharma, ada seorang Brahma yang bernama Sahampati yang berjalan mengelilingi Sang Buddha yang sedang duduk di bawah pohon Bodhi. Beliau mengelilingi Sang Buddha sebagai wujud penghormatan beliau terhadap Guru. Brahma Sahampati mengelilingi Sang Buddha sebanyak tiga kali sesuai dengan arah perputaran jarum jam.

Perlakuan Brahma Sahampati itu kemudian diulang kembali dan diikuti oleh semua murid Sang Buddha dan akhirnya menjadi suatu ritual untuk menghormati Sang Buddha ketika saat mangkat mereka melihat Yang Arya Maha Kassapa melakukan pradaksina tersebut.

Alkisah pada waktu Sang Buddha parinibbana, sesaat setelah itu keresahan para murid beliau mulai tampak, apalagi ketika Yang Arya Maha Kassapa, salah satu murid teladan beliau yang sangat dikagumi kebijaksanaannya belum tiba di Kusinara, salah satu kota di India, tempat tubuh Sang Buddha disemayamkan belum dapat dikremasi karena masih menunggu Yang Arya Maha Kassapa tersebut. Begitu Yang Arya Maha Kassapa tiba, beliau menghormat dengan cara membacakan paritta-parittadan kemudian berkeliling mengelilingi tubuh Sang Buddha sebanyak tiga kali searah jarum jam dari kiri ke kanan. Sejak saat itulah wujud penghormatan terhadap Sang Buddha berupa puja bakti berupa pembacaan paritta dan pradaksina lahir.

Seiring perkembangan agama Buddha, ritual pradaksina tetap dilakukan hingga saat ini, namun berbagai persepsi dan interpretasi dari berbagai pihak pun timbul tentang konsep arah perputaran dan jumlah perputaran tersebut, yaitu sebanyak tiga kali.

Secara umum, dikatakan bahwa konsep arah perputaran dalam berpradaksina ini didasarkan pada keadaan dunia yang terus berputar mulai dari matahari yang terbit di Timur kemudian tenggelam di Barat begitu seterusnya, hari-hari selanjutnya terus berputar. Oleh karena itulah pradaksina dilakukan dengan berkeliling searah perputaran jarum jam. 
Konsep lain mengenai jumlah perputaran sebanyak tiga kali, tidak disebutkan secara jelas di dalam Maha Parinibbana Sutta, mengapa baik Brahma Sahampati mengelilingi Sang Buddha dan Yang Arya Maha Kassapa mengelilingi jenasah Sang Buddha sebanyak tiga kali. Jadi perilaku tersebut hanyalah didasarkan pada Brahma Sahampati, sebagai orang pertama yang melakukannya sebanyak tiga kali, maka selanjutnya diikuti oleh yang lainnya dengan Yang Arya Maha Kassapa sebagai panutan yang menjadi teladan dalam melakukan pradaksina tersebut.

Persepsi lain mengenai jumlah perputaran dalam pradaksina adalah melalui interpretasi dari konsep dibangunnya Candi Borobudur yang merupakan salah satu bangunan religius agama Buddha berupa stupa raksasa berundak. Hal ini didasarkan pada tiga bagian Candi Borobudur, yaitu Kamadhatu, Rupadathu, dan Arupadathu. Dari sinilah terdapat alasan, mengapa dalam beraktivitas pradaksina dilakukan sebanyak tiga kali. Namun di beberapa kompleks vihara atau arama yang luas, pradaksina dilakukan dengan mengelilingi seluruh kompleksmaka biasanya pradaksina hanya dilakukan satu kali.

\section{Dua Jenis Aktivitas Pradaksina}

Akibat munculnya berbagai mashab dalam perkembangan agama Buddha yang mengakibatkan munculnya tata upacara puja bakti yang berbeda, turut melahirkan pula aktivitas puja bakti berupa pradaksina yang berbeda di setiap tradisi. Atas dasar pembagian dua mashab besar dalam agama Buddha, maka dapat dibedakan pula aktivitas pradaksina menurut makna, pelaksanaan, dan perwujudannya, yaitu:

\section{A. Pradaksina dalam Tradisi Theravada}

Sesuai dengan sejarah awal mula pradaksina, para penganut tradisi Theravada tetap mempertahankan konsep pradaksina dengan tujuan sebagai penghormatan terhadap Triratna (Buddha, Dharma, Sangha). Makna penghormatan inilah yang sebenarnya lebih ditekankan dalam melakukan pradaksina, sedangkan pradaksina itu sendiri hanya merupakan sebuah ritual yang dibakukan dengan dasar mengikuti dari yang terdahulu melakukannya. Perwujudan penghormatan terhadap Triratna menurut pandangan Theravada tidak hanya diwujudkan dalam puja bakti saja, namun juga oleh penerapan Dharma dalam kehidupan sehari-hari. Menurut tradisi Theravada, banyak cara untuk melakukan penghormatan, bukan hanya melalui pradaksina saja. 
Mengingat pradaksina adalah wujud paling nyata dalam melakukan penghormatan. Oleh karena itu, pradaksina menjadi kegiatan yang penting sekaligus tak penting. Adapun maksud dari pernyataan tersebut terwujud dalam pelaksanaan pradaksina dalam puja bakti menurut tradisi Theravadayang hanya dilakukan pada hari-hari raya besar agama Buddha, sedangkan dalam melaksanakan puja bakti sehari-hari, pradaksina jarang sekali dilakukan.

\section{B. Pradaksina dalam Tradisi Mahayana}

Lain halnya dengan tradisi Theravada, dalam tradisi Mahayana, pradaksina dilakukan setiap kali puja bakti dilakukan. Esensi dari berpradaksina dalam pelaksanaan puja bakti secara tradisi Mahayana adalah bermeditasi dengan cara berjalan. Ini merupakan salah satu praktik meditasi, yang disebut Vippasana Bhavana.

Dalam melaksanakan pradaksina secara tradisi Mahayana, sikap berjalan berkeliling ini dikombinasikan dengan sikap tubuh lain,yaitu sikap anjali dan sikap mudra sambil melafalkan sebuah kalimat pujian penghormatan. Aktivitas ini bertujuan meningkatkan konsentrasi dan kesadaran. Makna penghormatan dari aktivitas pradaksina dalam tradisi Mahayana ini menjadi tidak begitu penting. Usaha melatih diri untuk meningkatkan batin akan konsentrasi dan kesadaran inilah sesungguhnya yang perlu digarisbawahi.

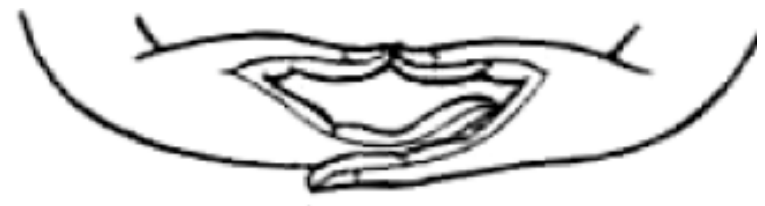

Gambar 4.Sikap Tangan Mudra Sumber: Database Pemuda Vihara Vimala Dharma, 2000

\section{Stupa sebagai Sarana Puja Bakti dalam Agama Buddha}

Ada dua macam tipe arsitektur menurut fungsinya dalam perkembangan arsitektur religius agama Buddha. Yang pertama yaitu tipe arsitektur yang berfungsi untuk menampung berbagai kebutuhan dalam kehidupan beragama seperti kebutuhan untuk melakukan puja bakti, tempat meletakkan objek penghormatan, perpustakaan atau sebagai tempat tinggal para anggota Sangha; dan yang kedua adalah tipe arsitektur yang berfungsi sebagai objek penghormatan dan puja bakti itu sendiri.

Tipe arsitektur yang pertama ini, bisa berupa bangunan arama, vihara, maupun cetiya; sedangkan tipe kedua biasanya berupa stupa atau pagoda. Di dalam sebuah kompleks arama atau vihara yang luas, biasanya juga terdapat arsitektur stupa yang seringkali menjadi focal point dari keseluruhan bangunan yang terdapat pada kompleks tersebut. 
Secara fungsional tipe arsitektur sebagai sarana yang digunakan untuk wadah melakukan aktivitas puja bakti agama Buddha dibedakan menjadi lima macam sarana puja bakti, yaitu:

1. Arama

Arama dalah sebuah kompleks vihara yang besar, pada dasarnya, fungsi yang terdapat pada sebuah arama tidak banyak jauh berbeda dengan vihara. Perbedaannya secara jelas terlihat dari pengolahan tapaknya saja, tempat arama tersebut biasanya terdapat tamantaman yang luas.

2. Vihara

Sebuah vihara yang lengkap biasa terdiri atas:

- Uposathagara (Gedung Uposatha)

- Dhammasala

Dhammasala atau Dharmasala merupakan tempat melakukan puja bakti dan mendengarkan pembabaran Dhamma atau diskusi Dhamma, juga sebagai tempat meditasi.

- Kuti

Adalah tempat tinggal para bhikkhu, bhikkhuni, samanera atau samaneri.Kuti ini biasanya terpisah dari tempat yang banyak dikunjungi umat. Bersifat privat.

- Perpustakaan

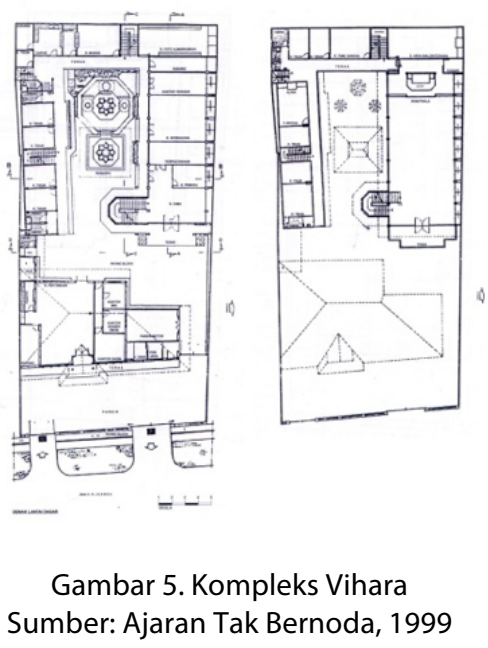

3. Cetiya

Cetiya merupakan tempat puja bakti bagi umat Buddha yang memiliki sarana yang lebih sederhana dibandingkan dengan vihara atau arama. Pada umumnya, di dalam sebuah cetiya hanya terdapat dharmasala berukuran kecil dan altar. 


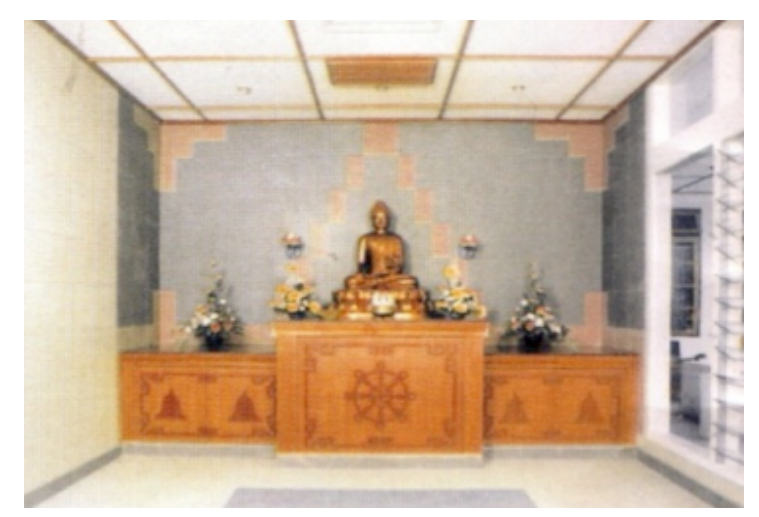

Gambar 6. Ruang Cetiya

Sumber: Ajaran Tak Bernoda, 1999

\section{Candi}

Fungsi candi sebagai sarana puja bakti, hampir mirip dengan stupa, merupakan ekspresi yang lebih kompleks dari stupa. Candi merupakan perwujudan dari sebuah mandala atau cakra yang menggambarkan dunia yang berputar dalam lingkaran samsara. Hanya saja, biasanya candi berupa kompleks, bukan bersifat monolitik seperti stupa.

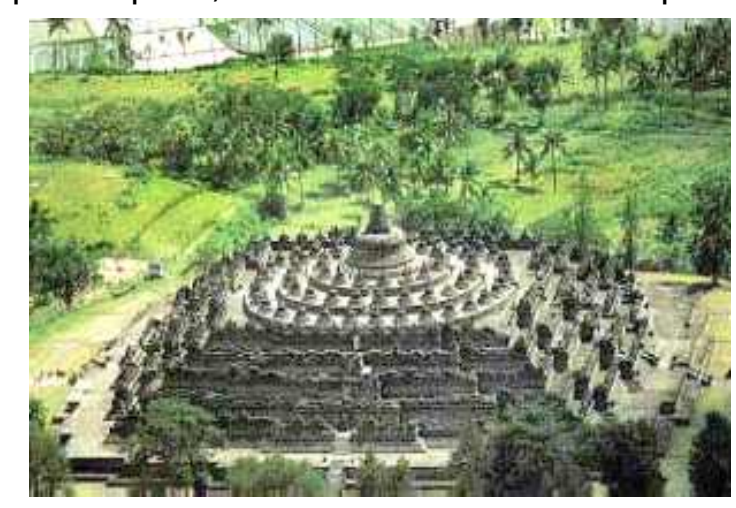

Gambar 7. Candi Borobudur Sumber: Database PVVD, 2000

\section{Stupa}

Stupa adalah suatu arsitektur monumental yang dibangun dengan tujuan untuk penempatan sisa kremasi dari seorang suci atau Buddha, maupun seorang raja sejagat. 
Pada mulanya terdapat berbagai keraguan dari berbagai pihak, apakah stupa sebuah arsitektur atau skulptur. Senake Bandaranayake menyatakan: "It lies somewhere between architecture and sculpture."Pembuktian stupa sebagai sebuah karya arsitektur ditinjau dari segi bahan bangunan dan cara membangunnya, penggunaan struktur dan konstruksi serta detil dan arsitektur yang cukup familiar di bidang arsitektur, serta kualitas fisik spasialnya, mengacu pada sebuah kesimpulan bahwa stupa merupakan sebuah bentuk arsitektur. Seperti halnya bangunan struktural lainnya, stupa tidak memiliki ruang interior. Stupa merupakan sebuah 'freestanding structure' yang tidak memiliki fungsi utilitas tertentu, kecuali sebagi tempat penyimpanan dan perlindungan relik atau benda lain yang berada di dalamnya, baik secara fisik maupun metafisik.

'Stupa' atau 'Tumuli' dalam Bahasa Sansekerta atau 'Thupa' dalam Bahasa Pali, atau 'Pagoda' dalam Bahasa Burma, 'Dagoba' dalam Bahasa Sinhalese atau Srilangka adalah suatu monumen yang didirikan sebagai tempat penyimpanan relik atau abu jenasah sisa kremasi dari para manusia suci atau cakkavati. Di Tibet, stupa dinamakan mch'od-rtens atau chorten.

Menurut Sinhalese Monastic Architecture, pada dasarnya sebuah stupa adalah monumen untuk berbentuk padat, berisi abu atau tulang para orang besar dan pahlawan. Bangunan ini merupakan warisan dari suku bangsa Kurgan kuno di India dan dibangun di setiap penjuru perempatan jalan untuk memperingati jasa dari orang besar atau pahlawan tersebut.

Dalam sejarah, penentu bentuk dan tatanan stupa didapat dari Sang Buddha melipat jubahnya menjadi segiempat, kemudian meletakkan patta dalam posisi terbalik, dan tepat di atas alas mangkuk tersebut diberdirikan tongkat jalan beliau. Ketiga komposisi elemenelemen sederhana yang digunakan oleh Sang Buddha sebagai alat pemenuhan kebutuhan beliau pada waktu menyebarkan ajaran beliau, membentuk suatu paduan komposisi yang 
dikatakan sebagai stupa. Ketiga elemen tersebut merupakan tiga ciri utama stupa, bahwa stupa terdiri atas sebuah dasar persegi, sebuah tutup setengah bulat, dan puncak berbentuk penampang bundar yang panjang.

Fungsi stupa pada awalnya diungkapkan oleh Sang Buddha sendiri kepada salah satu murid beliau bernama Ananda ketika Bhikkhu Ananda bertanya kepada beliau tentang cara menghormati jenasah seorang Buddha, bahwa untuk menghormati jenasah seorang Buddhasama halnya dengan menghormati jenasah seorang cakkavati. Adapun cara menghormat tersebut sesuai ucapan Sang Buddha, yaitu: "Jenasah seorang cakkavati, mulamula dibungkus dengan kain linen baru, kemudian diikat dengan kain wol, katun ... dengan demikian jenasah cakkavati dikremasikan. Di persimpangan jalan, didirikan stupa untuk cakkavati itu ... Demikian pula seharusnya dilakukan pada jenasah Tathagata ..."

Munculnya stupa, menjadikan bentuk ini sebagai sebuah image awal dari Buddha, yang pada saat ituimage Buddha lainnya berupa patung Buddha, gambar Buddha, dan sebagainya belum muncul. Hal ini juga disebabkan karena bentuk arsitektur inilah yang muncul pertama kali setelah Sang Buddha Parinibbana. Luasnya image Buddha di seluruh dunia dalam perwujudan stupa ini disebabkan oleh maraknya pembangunan stupa-stupa yang bersifat monumental sebagai penanda tempat bersejarah agama Buddha, juga disebabkan adanya distribusi relik maupun benda-benda peninggalan Sang Buddha ke seluruh dunia secara kolosal oleh Raja Ashoka di India, yaitu dengan membuat stupa sebanyak 84.000 buah pada akhir tahun 481 SM.

\section{Bentuk, Fungsi, dan Makna Stupa}

Dalam arsitektur Hindu dan Buddha, ada beberapa persamaan yang terdapat pada ekspresi arsitekturnya, di antaranya tentang superstruktur dari karya-karya arsitektur Hindu dan Buddha. Ada tiga bagian yang melandasi lahirnya bentuk arsitektur Hindu dan Buddha, yaitu bagian kepala, badan, dan kaki. Ketiga bagian ini menggambarkan keadaan makro kosmos dunia yang terdiri atas tiga alam, yaitu alam atas, tengah dan bawah. 


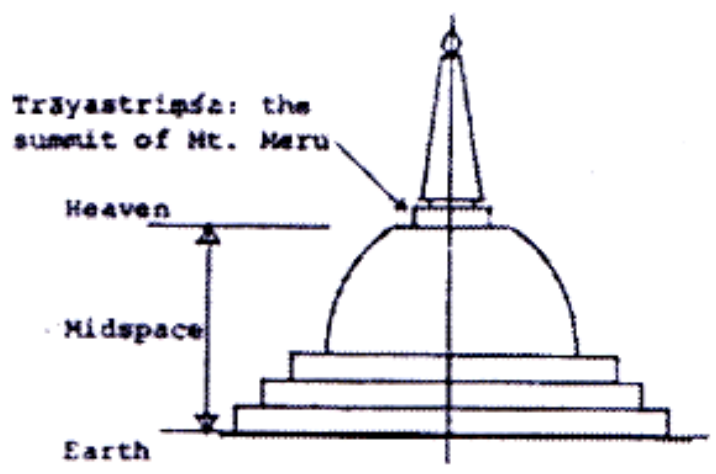

Gambar 9. Tribuwana dari Makro Kosmos Dunia Sumber: Koleksi Charles Sudianto Aly, 2002

Sama halnya seperti bentuk arsitektur Hindu dan Buddha lainnya, stupa secara garis besar, terdiri atas tiga bagian utama. Telah dijelaskan sebelumnya bahwa stupa terbentuk dari tiga elemen (jubah terlipat, mangkuk terbalik, dan tongkat jalan). Dari ketiga elemen tersebut, berdasarkan bentuk geometrisnya, maka sebuah stupa terdiri atas tiga bagian utama, yaitu bagian dasar stupa, kubah, dan bagian puncak. Ini sekaligus menggambarkan konstruksi dari sebuah stupa.

Tiga bagian utama stupa tersebut diuraikan menjadi:

\section{Bagian Dasar Stupa}

Bentuk dasar dari bagian dasar ini berupa persegi yang memiliki ketebalan tertentu. Dalam perwujudan bangunan stupa sebagai candi, bagian dasar ini memiliki konsep mandala atau cakra, karena pada dasarnya sebuah candi adalah sebuah mandala raksasa. Hal ini juga dikarenakan konsep candi yang juga menggunakan konsep kepala, badan dan kaki.

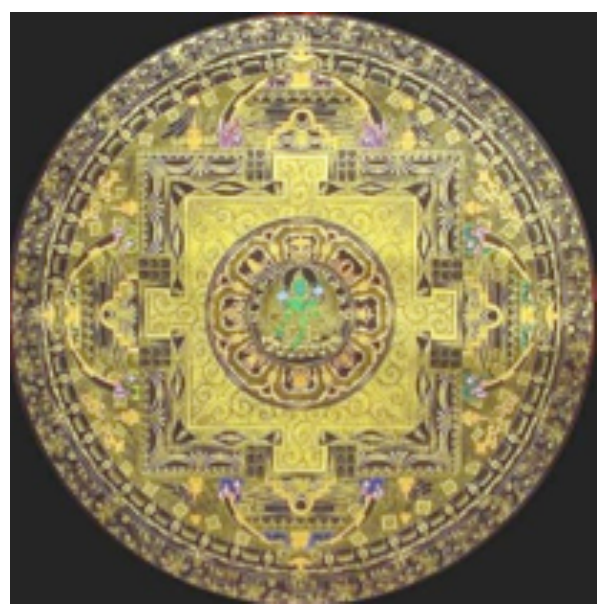

Gambar 10. Contoh Mandala Sumber: Database PVVD, 2000 
Di Srilangka, dasar dari stupa ini berbentuk lingkaran, mengikuti bentuk kubah stupa. Hal ini yang membuat arsitektur stupa di Srilanka berbeda dengan stupa-stupa yang berada di negara lain. Ciri ini kemudian menjadi ciri dari arsitektur religius agama Buddha di Srilanka selanjutnya, yaitu stupa dengan dasar lingkaran.

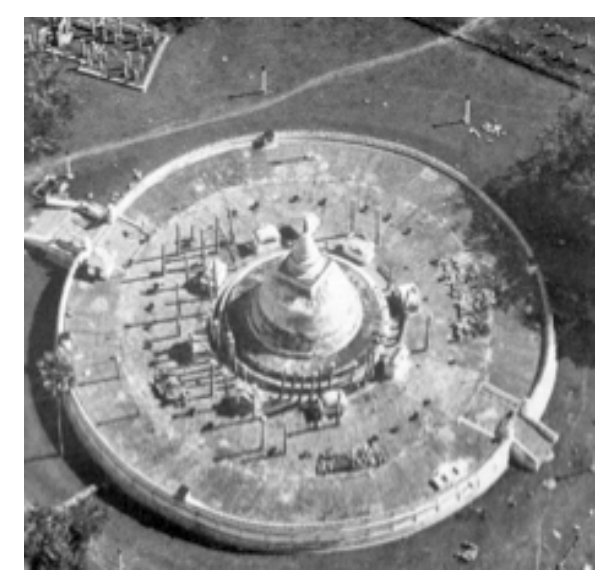

Gambar 11. Alas Stupa Berbentuk Lingkaran Sumber: Sinhalese Monastic Architecture, 1974

\section{Bagian Kubah}

Bentuk dasar dari bagian kubah ini adalah setengah bola. Namun dalam ekspresi arsitekturnya, terdapat enam macam tipe bentuk kubah yang biasa dipakai untuk membuat stupa, yaitu:

\section{a. Ghantakara}

Tipe kubah yang mengacu pada bentuk lonceng atau genta.

b. Padmakara

Tipe kubah ini didasari dari bentuk kelopak bunga teratai.

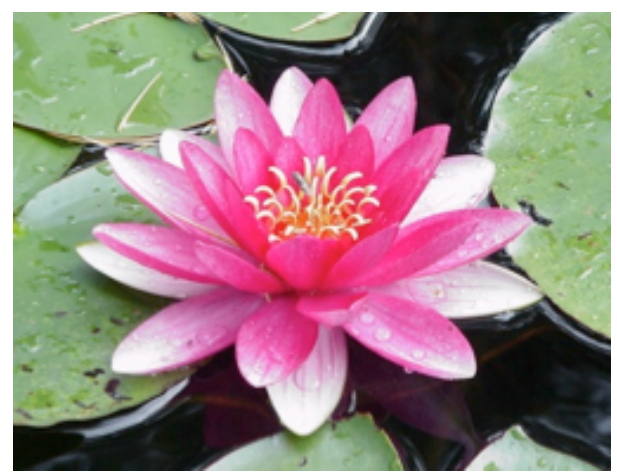

Gambar 12. Bunga Teratai Sumber: Database PVVD, 2000

c. Dhanyakara 
Tipe kubah yang seperti tumpukan atau timbunan batang-batang padi atau jerami yang membumbung.

d. Ghatakara

Tipe kubah berbentuk seperti pot tanaman yang terbalik.

e. Amalakara

Tipe kubah ini mengambil bentuk seperti buah Nelli atau Amala.

f. Bubbulakara

Tipe kubah dengan mengambil bentuk dari gelembung sabun yang menempel pada lantai.

Konsep lain mengatakan bahwa kubah diibaratkan sebagai bentuk telur yang mau muncul ke permukaan yang melambangkan sebuah kelahiran.

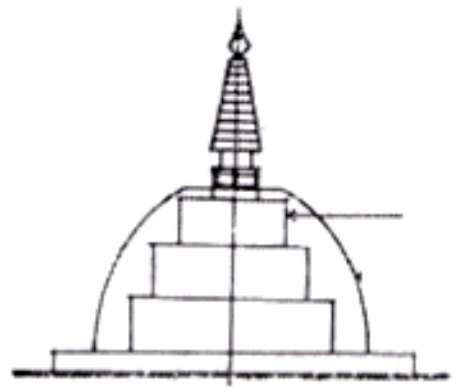

Telur Muncul

Gambar 13. Kubah Telur

Sumber: Koleksi Charles Sudianto Aly, 2002

Lain lagibentuk kubah yang setengah bulat ini didefinisikan sebagai cakrawala yang bulat juga, yang menampakkan diri secara konkret, tetapi sebagai sebuah tipuan. Ini mengandung makna bahwa dunia adalah maya, dan diri kitalah yang harus terbebaskan dari segala sesuatu yang bersifat maya tersebut. Pembebasan ini yang disebut mencapai Nibbana.

\section{Bagian Puncak Stupa}

Bagian puncak stupa yang didasari dari bentuk tongkat jalan, maka seperti halnya bentuk lingga dalam arsitektur Hindu, bagian ini memiliki bentuk dasar panjang mencuat ke atas. 


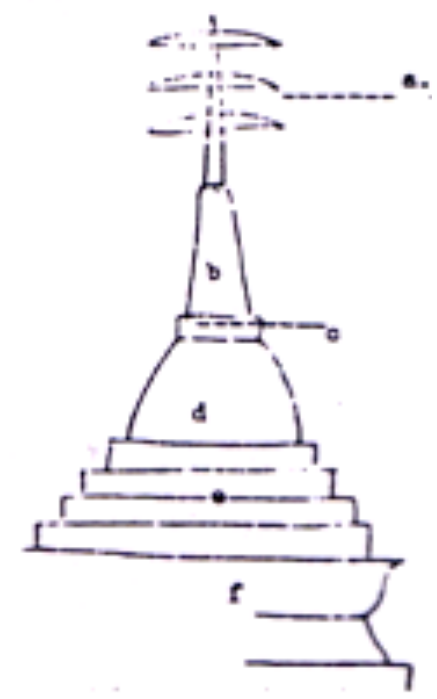

Gambar 14. Chorten Tibet

Sumber: Makna Candi Bharabudur-Mendut

Berdasarkan uraian tiga bagian utama di atas, arsitektur stupa kemudian berkembang di seluruh dunia dalam berbagai ekspresi, fungsi dan makna. Hal ini disebabkan oleh berbagai faktor, seperti ragamnya interpretasi akan makna dan tujuan dibuatnya sebuah stupa, tipe arsitektur di berbagai negara, gaya dan langgam seni yang berbeda di setiap negara, dan lain-lain. Namun dari berbagai ekspresi, fungsi dan makna yang beragam tersebut, terdapat stupa dengan bentuk, fungsi, dan makna yang masih asli menurut para pakar.

Secara lengkap, stupa yang asli terdiri atas enam bagian dengan masing-masing bagiannya memiliki makna tersendiri. Adapun keenam bagian stupa tersebut adalah sebagai berikut:

\section{Padanama}

Bagian dasar stupa yang berbentuk persegi ini melambangkan saddha yang berarti keyakinan yang menggambarkan kemajuan batin spiritual menuju jalan keBuddhaan.

\section{Paravalalu}

Bagian bawah yang menopang kubah ini terdiri dari tiga lingkaran atau cincin yang melambangkan Triratna, yang terdiri atas Buddha, Dhamma, dan Sangha. Simbol ini melambangankan perlindungan umat Buddha terhadap Tiga Permata tersebut.

\section{Gaba atau Garbhaya}

Kubah berbentuk setengah bola ini melambangkan Buddha Sasana yaitu ajaran Sang Buddha yang disampaikan langsung oleh Sang Buddha sendiri.

4. Devatakutowa 
Bagian penutup kubah tersebut yang berbentuk persegi kecil terdiri atas empat sisi melambangkan ajaran utama Sang Buddha tentang kehidupan ini yaitu Cattari Ariya Saccani.

\section{Kot Karalla}

Bentuk spiral yang terdapat di atas Devatakutowa ini terdiri atas delapan cincin yang semakin mencuat ke atas. Elemen ini melambangkan ajaran Buddha lainnya yaitu Arya Atthangika Magga.

6. Kota

Bagian teratas dari stupa yang biasa disebut sebagai mahkota melambangkan tujuan akhir dari umat Buddha yaitu mencapai Nibbana.

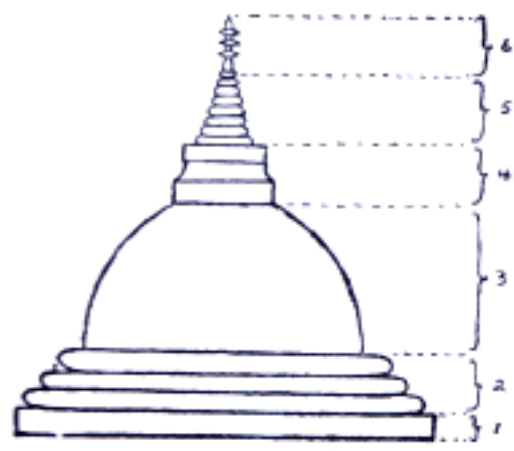

Gambar 15. Bagan Stupa asli Sumber: Buddhist Worship, 1993

Secara umum dan keseluruhan, berdasarkan sejarah dan latar belakang munculnya sebuah stupa, dikatakan bahwa stupa adalah simbol dari Nibbana. Perkembangan arsitektur stupa juga merupakan perkembangan bentuk, fungsi dan makna stupa itu sendiri. Munculnya berbagai perbedaan akan stupa mencerminkan kayanya seni dalam arsitektur, khususnya arsitektur stupa.

Berangkat dari fungsi dasar tersebut, fungsi stupa kemudian berkembang lagi menjadi fungsi-fungsi lain, mulai dari fungsi stupa sebagai prasasti untuk menandakan tempat bersejarah pada masa The Primitive Buddhism hingga stupa yang hanya sebagai simbol penanda bangunan umat Buddha.

Lain halnya fungsi stupa menurut Remusat. la berpendapat bahwa sebuah stupa bukanlah dibangun di atas makam atau sebagai tempat untuk menyimpan abu maupun relik dari seorang manusia suci, namun sebagai lambang dari Panca Bhuta, lima unsur pembentuk jasmani manusia (udara, cahaya, api, air,dan bumi), lambang dari sebuah susunan kosmis. 
Bilamana seseorang meninggal, maka kelima unsur ini akan terurai kembali kepada asalnya dari sesosok jenazah.

Stupa yang merupakan lambang dari Panca bhuta tersebut dapat dilihat dalam susunan stupa menurut tradisi Tibetyaitu chorten.
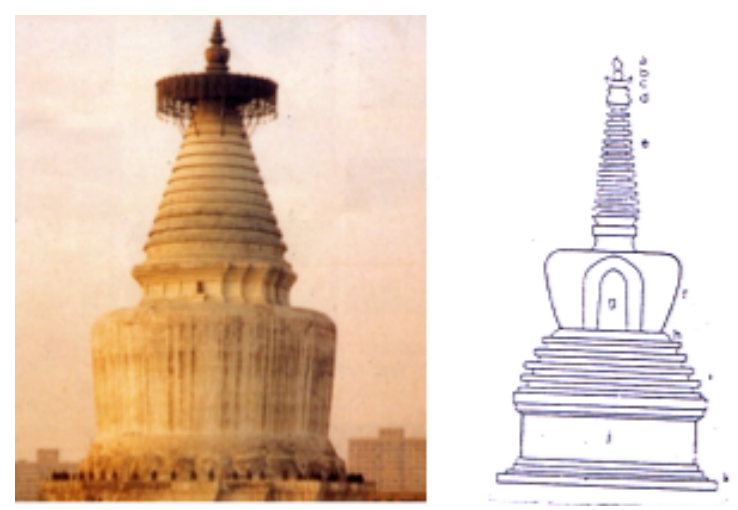

Gambar 16. Chorten Gyantse Sumber: Buddhist Art \& Architecture, 1993

Masing-masing dari lambang ini diberi nama huruf yang berasal dari bahasa Dewa Nagari, yang berarti:

a. Segi empat

Merupakan lambang dari $A$, yang berarti tanah atau bumi.

b. Bulat

Merupakan lambang dari Va, yang berarti air.

c. Segitiga

Merupakan lambang dari Ra yang berarti api.

d. Bulan Sabit

Merupakan lambang dari Ka yang berarti sinar atau cahaya.

e. Bulat kecil dengan nyala api

Merupakan lambang dari Kha yang berarti udara

Menurut Paul Mus, fungsi dan makna stupa berbeda dengan pendapat Remusat di atas. Paul Mus membagi stupa menjadi 5 bagian, yaitu: 


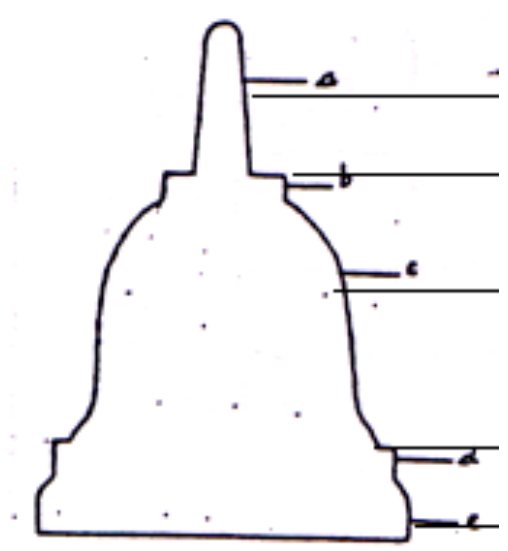

Gambar 17. Stupa Versi Paul Mus Sumber: Makna Candi Bharabudur-Mendut, 1987

\section{Hti / Yasti/Cetya}

Merupakan bagian paling atas dari sebuah susunan bangunan stupa yang mencuat ke atas. Bagian atasnya lagi, kadangkala diberi tambahan berupa Chattravali (payung). Hti mirip dengan sebuah bangunan Lingga dalam agama Hindu, sebuah bangunan yang berbentuk tiang lurus satu batang yang mencuat ke atas. Orang seringkali menyebutnya dengan istilah Menhir. Bentuk ini merupakan lambang dari pohon kehidupan yang menjulur jauh ke atas menuju tiada terhingga.

$H$ ti pada umumnya berbentuk prisma segilima, enam, atau delapan. $H t i$ yang berbentuk prisma segidelapan ini merupakan perlambang dari jalan utama utama beruas dalam agama Buddha (Arya Atthangika Magga).

Chattravali yang biasanya terletak di puncak stupa ini berbentuk dan berfungsi seperti payungsebagai pengungkapan kekuasaan kosmis. Ini sesuai dengan makna payung di negara-negara Timur yang berupa pohon sebagai lambang semesta alam, gunung sebagai tempat teratas, poros, atribut surgawi dan kekuasaan para raja. Hal ini diwujudkan kemudian dalam suatu perilaku bahwa raja-raja, khususnya di Thailand, Jawa, Bali, dan sebagainya selalu disertai tanda-tanda kemartabatannya dengan payung. Kembali pada fungsi awal stupa untuk menyimpan relik dari orang suci atau raja-raja, elemen payung ini juga berusaha menunjukkan eksistensi dari raja tersebut, apakah dia seorang raja dari segala raja atau seorang raja dari kerajaan kosmis. 


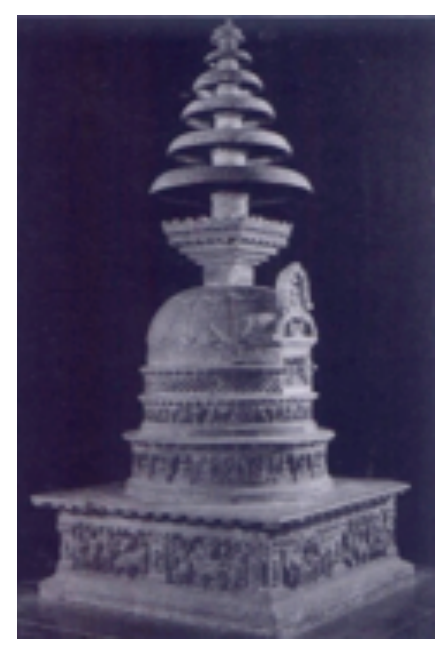

Gambar 18. Chorten Payung Bersusun Sumber: Buddhist Art and Architecture, 1993

\section{Harmika / Catussurakostha}

Bagian stupa yang berbentuk segiempat seperti daun meja yang berada diatas cupola, merupakan altar. Bentuk ini melambangkan keadaan di luar tata kehidupan duniawi, diluar kelahiran dan kematian. Di dalam bagian ini, dilaksanakan pengorbanan atas dasar kesadaran, pengorbanan atas semua bentuk nafsu duniawi dan ragawi yang merupakan lambang bagian alas/dasar stupa. Sang Buddha bersabda: “Pengorbanan yang berharga hanyalah satu, yaitu pengorbanan nafsu indriawi“. Dengan kata lain, Harmika adalah lambang dari pelepasan nafsu secara sadar.

Di Khatmandhu, Nepal, pada Harmika seringkali digambar sepasang mata yang bersamadhi. Mata ini merupakan lambang dari Agni (unsur api)
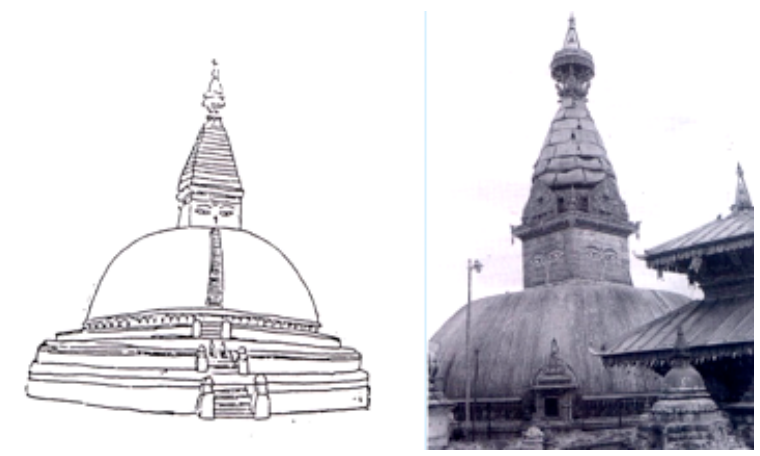

Gambar 19. Stupa Anuradhapura, Srilanka Sumber: Sinhalese Monastic Architecture, 1974

\section{Cupola / Gantha / Anda / Dhatugharba}

Merupakan lanjutan dari bagian Medhi, berbentuk seperti telur yang berdiri. Cupola merupakan lambang dari semesta cakrawala yang berisi gaya membangun dan merombak, 
lahir dan mati, sebagai air dan telur. Telur disini melambangkan diri manusia. Menurut mitologi klasik India, telur sebagai benih kehidupan merupakan lambang dari tenaga yang tersimpan. Dari telur inilah akan lahir benih bathin yang utama dan berbudi luhur.

\section{Medhi}

Lipatan jubah Sang Buddha yang mendasari bentuk stupa, pada perkembangan selanjutnya diubah menjadi bentuk lingkaran. Bagian inilah yang disebut Medhi, yang merupakan dasar dari Cupola. Bentuk lingkaran merupakan lambang dari pemusatan pikiran, melanjutkan bentuk setengah bola (hemispheer) yang berarti bahwa dalam melakukan meditasi, pikiran dipusatkan pada alam semesta raya yang tiada batasnya.

\section{Upapitha}

Merupakan dasar stupa yang berupa alas utama berbentuk segiempat, yang merupakan lambang dari kehidupan duniawi yang penuh nafsu/kama, kehidupan indriawi. Pada luar bangunan stupa juga biasanya terdapat pagar yang membatasi daerah stupa dan daerah luar. Pagar ini dinamakan vedika, yang melambangkan batas antara kehidupan duniawi yang bersegi-segi dan alam kesucian.

Versi lain dari sebuah stupa Tibetan-Nepal, stupa yang terdiri atas tiga bagian utama melambangkan tiga sikap yang terurai lagi menjadi delapan jalan utama menuju tujuan akhir, yaitu Sila, Samadhi dan Panna.
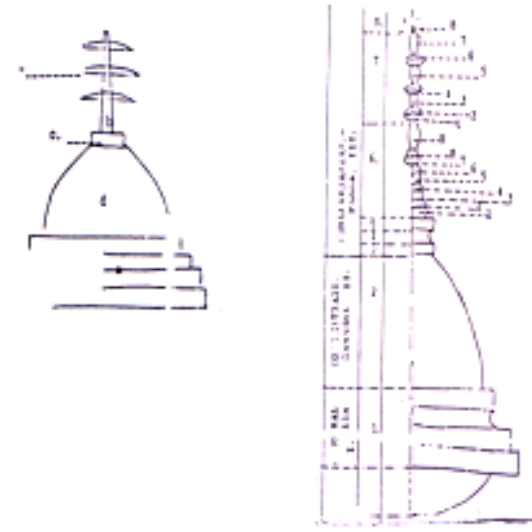

Gambar 20. Stupa Lambang 8 Jalan Utama Sumber: Makna Candi Bharabudur-Mendut, 1987

Sebagai fungsi pengganti image seorang Buddha, ada yang berpendapat juga bahwa stupa adalah visualisasi dari tubuh Buddha. Perbandingan ini dibagi menjadi tiga bagian, yaitu:

1. Bagian puncak stupa yang merupakan perwujudan dari unisasiraskata (ubun-ubun seorang Buddha yang menonjol) yang melambangkan tingkat kesempurnaan dan kebijaksanaan tertinggi.

2. Bagian tengah berupa kubah sebagai perwujudan tubuh Buddha. 
3. Bagian dasar berupa alas persegi yang merupakan perwujudan dari sikap padmasana, yaitu sikap duduk bersila seperti bunga teratai.

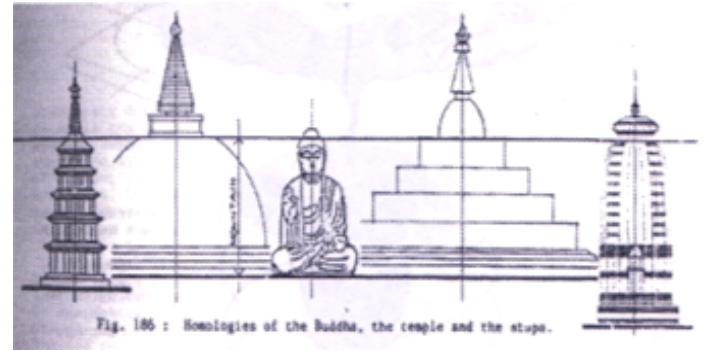

Gambar 21. Perbandingan Stupa dan Tubuh Buddha Sumber: Koleksi Charles Sudianto Aly, 2002

Menurut Y. B. Mangunwijaya, bentuk dan makna stupa merupakan perpaduan antara citra gunung dan tugu poros. Dalam sekian banyak kebudayaan, citra dasar gunung selalu dihayati selaku tanah tinggi yang merupakan tempat yang paling dekat dengan dunia atas, menuju ke yang tiada terhingga. Lebih spesifik lagi gunung yang dimaksud adalah Gunung Mahameru yang dianggap sebagai gunung suci yang sakral yang memang dianggap sebagai tempat tertinggi. Ini mirip dengan bangunan Meru pada arsitektur Hindu.

Pendapat lain mengatakan bahwa stupa membawa kebahagiaan, membawa rezeki, dan lambang dari sarva mangala. Bagi aliran esoterik, stupa dianggap sebagai Corak Samaya Maha Vairocana Tathagata. Corak Samaya berarti lambang Purva Pranidhana yang melambangkan hasil yang berhasil dicapai, seperti halnya golok dan pedang pada Vidyaraja Aryacalanatha, dan bunga teratai pada Avalokitesvara Bodhisattva, serta mudra-mudra para Buddha.

\section{Jenis - jenis Stupa}

Berdasarkan sifatnya, arsitektur stupa dapat dibedakan menjadi tiga tipe, yaitu:

1. Stupa yang bersifat monumental

2. Stupa yang bersifat bangunan (dapat dimasuki)

3. Stupa yang bersifat ornamental.

Pada awalnya, semua stupa bersifat monumental. Hal ini didasari pada fungsi stupa mulamula. Pada perkembangan selanjutnya, bentuk stupa kemudian dijadikan kulit dari bangunan vihara atau cetiya serta sebagai elemen ornamental pada bangunan religius agama Buddha sebagai identitas. 


\section{Stupa yang bersifat monumental}

Stupa yang bersifat monumental, biasanya berdimensi besar, dan monolitik sebagai 'freestanding' building. Untuk itu ada stupa yang bersifat monumental ini kemudian dibedakan lagi menjadi beberapa fungsi, antara lain:

a. Stupa untuk menandai tempat bersejarah Sang Buddha, seperti halnya sebuah prasasti.

Kira-kira 300 tahun SM, Maharaja Asoka membangun dua buah stupa untuk menandai tempat penting pada zaman Sang Buddha. Kedua stupa tersebut, yaitu:

- Chaukhandi Stupa

- Dhamekha Stupa

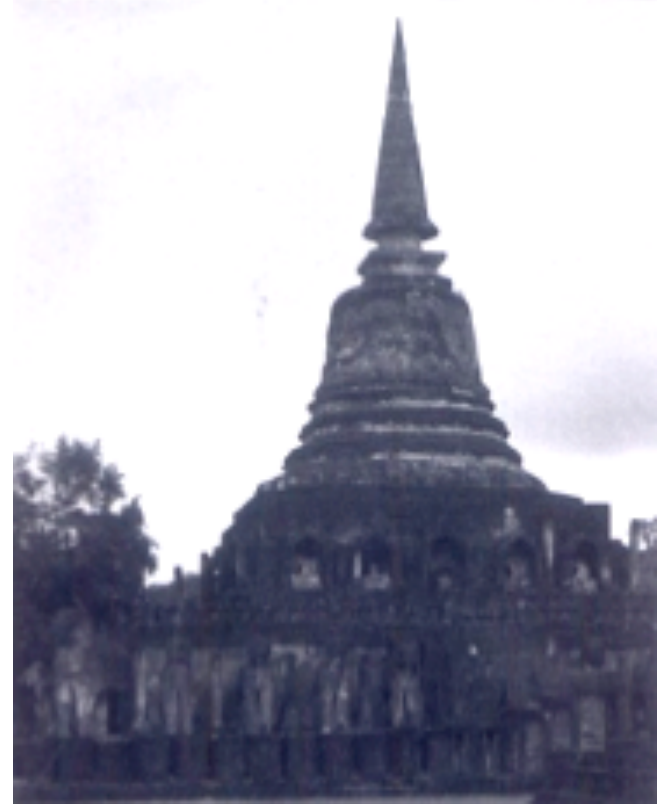

Gambar 22. Si Satchnalai, Thailand

Sumber: Buddhist Art and Architecture, 1993

b. Stupa untuk menyimpan relik Sang Buddha atau Arahat sebagai wujud penghormatan Stupa untuk menyimpan relik tersebar di seluruh dunia dengan berbagai dimensi. Peletakan stupa juga tidak selalu monolitik, namun juga stupa tersebut ditempatkan pada ruang interior. 


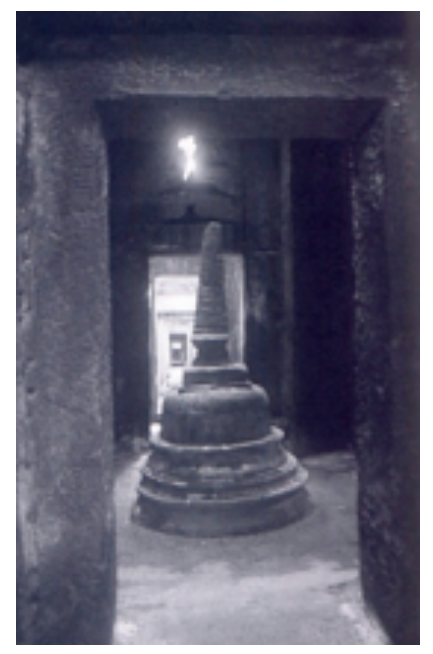

Gambar 23. Preah Khan Angkor, Kamboja Sumber: Buddhist Art and Architecture, 1993

Abu jasmani Sang Buddha yang dipuja sebagai rarira atau relik, pada umumnya disimpan di dalam sebuah stupa. Namun pada perkembangannya, jumlah relik tidak sebanding dengan jumlah stupa yang dibuat, sehingga pada zaman Raja Kaniskha, patung Buddha ataupun Kitab Suci kemudian diletakkan di dalam stupa.

C. Stupa sebagai focal point

Keberadaan stupa dalam sebuah kompleks arama atau vihara, sangat mencolok dan bersifat eye-catcher hingga menjadikan stupa sebagai focal point. Dimensi stupa yang hampir pada umumnya lebih besar dibanding bangunan lain dalam kompleks tersebut, menjadikan stupa semakin menonjol. Begitu pula dengan sifat bangunannya yang membentuk ruang interior, serta bentuk stupa yang memang unik semakin menonjolkan keberadaan stupa tersebut.

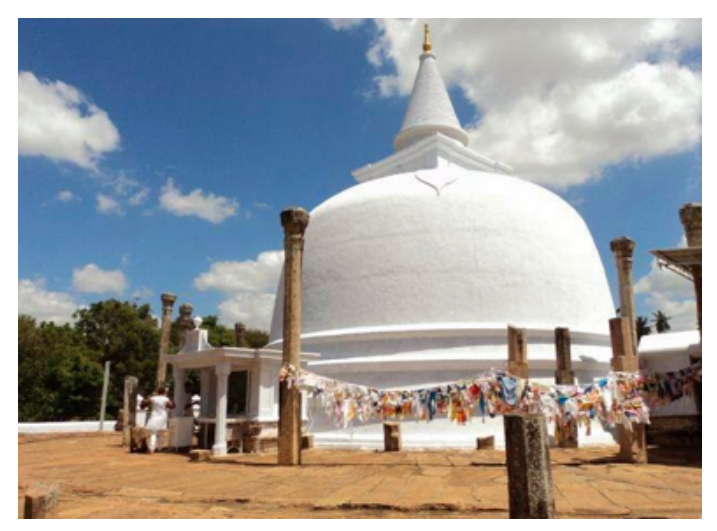

Gambar 24. Lankarama, Srilangka Sumber :Sinhalese Monastic Architecture, 1974 


\section{Stupa yang bersifat bangunan}

Keunikan bentuk stupa memicu munculnya bangunan-bangunan bernuansa stupa lainnya, namun dapat menampung kegiatan pada ruang interiornya. Ruang interior pada bangunan stupa tersebut berupa cetiya untuk penyelenggaraan aktivitas puja bakti. Jadi dalam hal ini, sebenarnya fungsi bangunan adalah berupa cetiya dengan ruang baktisala, namun dengan bentuk pembungkusnya menyerupai stupa. Jadi tidak bersifat solid.

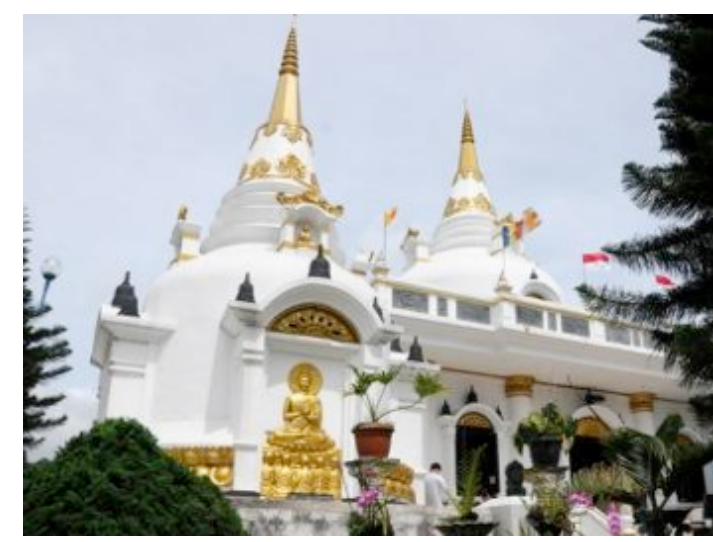

Gambar 25. Vipassana Graha Sumber: Dokumentasi Pribadi, 1999

\section{Stupa yang bersifat ornamental}

Pada sekarang ini di Indonesia, stupa banyak dibangun di tempat-tempat suci seperti vihara dan cetiya dengan dimensi yang jauh lebih kecil. Stupa ini dibuat bukan untuk tujuan menyimpan relik atau benda-benda suci, tapi hanya sebagai simbol dari tempat ibadah umat Buddha. Ini dilakukan oleh para peziarah untuk persembahan pada Sang Buddha sebagai wujud peringatan dan penghormatan.

\section{Analisis PeranAktivitas PradaksinaPada Bangunan Stupa}

Aktivitas pradaksina sebagai pembentuk wadah, dalam hal ini adalah bangunan stupa, memiliki beberapa peranan terhadap arsitektur, antara lain:

\section{Menentukan dimensi ruang yang terbentuk}

Dalam perwujudan pradaksina pada bangunan stupa, dimensi ruang yang tercipta dipengaruhi antara lain:

- Jumlah pelaku aktivitas

Banyak atau sedikitnya pelaku aktivitas sangat menentukan besaran ruangan yang terbentuk. Hal ini dikarenakan aktivitas yang dilakukan tidak membentuk beberapa layer, hanya satu layer saja dalam pelaksanaannya. 

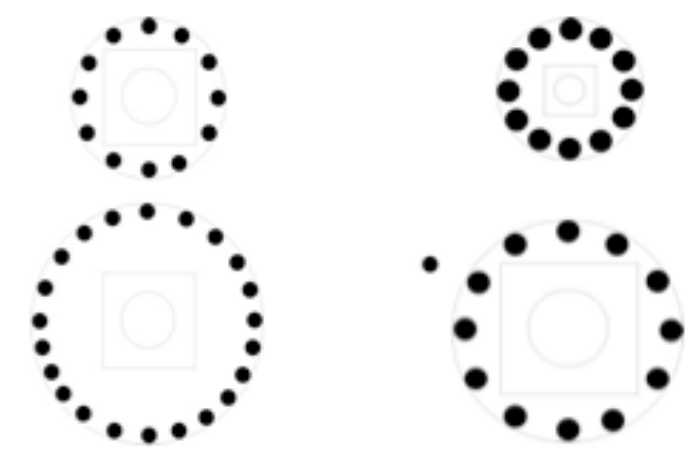

Gambar 26. Jumlah Pelaku sebagai Penentu Sumber: llustrasi Penulis, 2002

- Dimensi, proporsi dan skala bangunan stupa

Semakin besar dimensi bangunan stupa, semakin besar pula ruang positif yang dihasilkan. Begitu pula halnya dengan proporsi dan skala yang menyesuaikan dengan dimensinya, sehingga aktivitas pradaksina selain berperan membatasi ruang positif yang terbentuk, juga menentukan besaran dimensi ruang yang terbentuk. Hal ini berlaku untuk penghayatan ruang baik secara horizontal maupun vertikal.
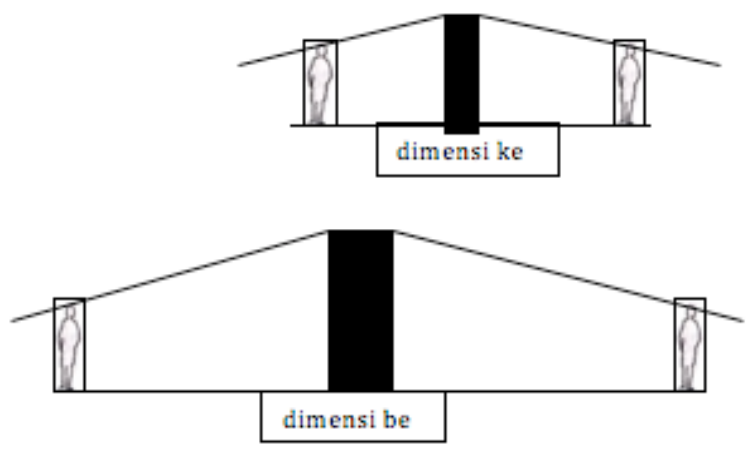

Gambar 27. Proporsi

Sumber: Ilustrasi Penulis, 2002

\section{Mempertegas kualitas ruang yang terbentuk}

Aktivitas pradaksina mampu membentuk ruang negatif menjadi positif.

Menurut A. E.Brinckmann, ada tiga konsep mengenai ruang, yaitu:

- Massa skulptural yang berdiri bebas dan dikelilingi oleh ruang

- Ruang yang dikelilingi oleh massa

- Kulminasi dari keduanya. 
Bangunan stupa yang pada dasarnya adalah sebuah massa skulptural, juga dikelilingi oleh ruang sebagai elemen fisik spasial. Oleh karena itu, ruang yang terbentuk akibat adanya massa tadi berupa ruang negatif.
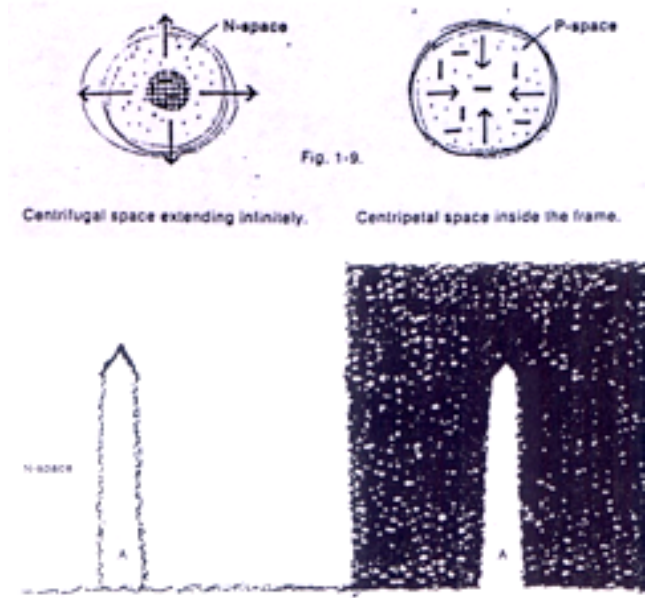

Gambar 28. Perbedaan Orientasi Menentukan Ruang positif dan Negatif Sumber: Exterior Design in Architecture, 1981

Hal ini dipengaruhi oleh:

- Jumlah pelaku aktivitas

Pradaksina yang dapat dilakukan secara perorangan maupun kelompok mempengaruhi ketegasan ruang yang terbentuk karena pelaku aktivitas dengan jumlah semakin banyak, maka ruang yang terbentuk pun semakin tegas.
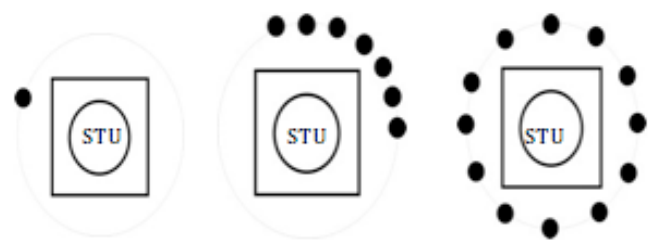

Gambar 29. Ketegasan Ruang Akibat Jumlah Pelaku Aktivitas Sumber: Ilustrasi Penulis, 2002

- Jarak antar pelaku dalam melakukan aktivitas
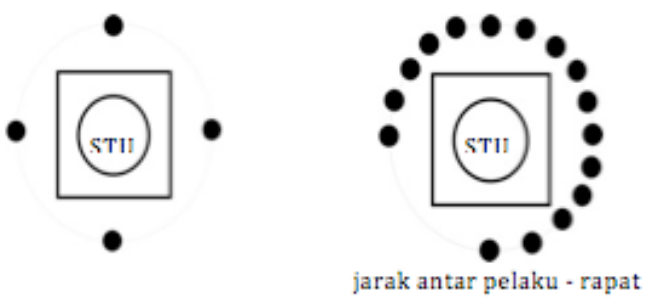

Gambar 30. Ketegasan Ruang Akibat Jarak antar Pelaku Aktivitas Sumber: Ilustrasi Penulis, 2002 
Dalam melakukan pradaksina, si pelaku harus melakukannya dengan kesadaran penuh,konsentrasi dalam berjalan berkeliling, jarak juga merupakan faktor untuk melatih kesadaran. Hal ini lebih lanjut juga berperan untuk mempertegas ruang negatif hingga menjadi ruang positif.

3. Menjadikan bentuk arsitektural / massa arsitektural sebagai orientasi dari ruang yang terbentuk
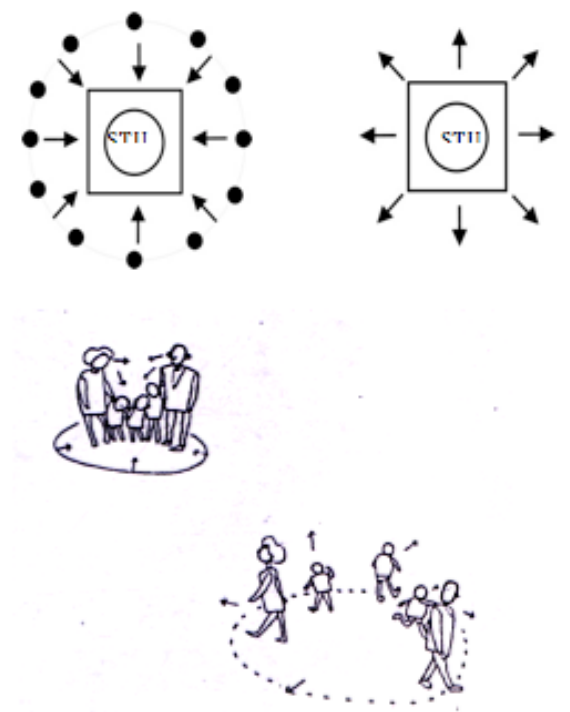

Gambar 31. Keberadaan Massa Mempengaruhi Orientasi Ruang Sumber: Ilustrasi Penulis, 2002

\section{Menjadikan stupa sebagai wadah arsitektur, bukan massa skulptural}

Arsitektur, yang mencakup hubungan antar ruang, fungsi, bentuk, dan keteknikan yang kesemuanya merupakan sebuah integritas. Bila salah satu komponen hilang, maka perlu dipertanyakan apakah hal tersebut masih merupakan arsitektur.

Pradaksina yang merupakan komponen fungsi, membutuhkan ruang sebagai wadah, serta bentuk stupa sebagai orientasi dari kegiatan puja bakti yang dilakukan. Oleh karena itu, hubungan antara pradaksina dan stupa inilah yang baru bisa dikatakan sebagai arsitektur.

\section{PENUTUP}

Atas dasar yang telah dibahas pada bagian sebelumnya, maka dapat disimpulkan bahwa baik pradaksina sebagai aktivitas dan bangunan stupa sebagai wadah aktivitas, keduanya memiliki keterkaitan dalam hal menentukan dimensi ruang yang terbentuk, mempertegas 
kualitas ruang yang terbentuk, menjadikan bentuk dan massa arsitektural sebagai orientasi dari ruang yang terbentuk, serta menjadikan stupa sebagai wadah arsitektur, bukan massa skulptural. Namun, adanya keterkaitan tersebut hanya berupa dampak secara spasial dan bukanlah merupakan perubahan secara hakiki akan makna spiritual yang terkandung pada pradaksina dan bangunan stupa sebagai ekspresi religius. Jadi tidak ada pergeseran makna yang terjadi pada keduanya.

Asal mula pradaksina dan bangunan stupa merupakan dua hal yang lahir sendiri-sendiri, tanpa adanya suatu kaitan tertentu serta muncul pada waktu yang berlainan. Namun pada perkembangan selanjutnya, keduanya saling berperan karenapradaksina sebagai aktivitas membutuhkan wadah, yaitu bangunan stupa sebagai tempat untuk melaksanakan puja bakti.

Pada bangunan stupa, pradaksina hampir tidak memberi pengaruh pada elemen fisik material. Peranan pradaksina pada bangunan stupa lebih mempengaruhi akan pembentukan elemen fisik spasial, tanpa merubah hakikat ruang yang terbentuk sebagaihakikat dari arsitektur itu sendiri.

Secara mental spiritual, dengan adanya aktivitas pradaksina yang dilakukan pada bangunan stupa, menjadikan bangunan stupa sebagi orientasi pusat dari mikrokosmos, dan sekaligus pusat dari makrokosmos.

Jadi, baik pradaksina maupun bangunan stupa, keduanya merupakan cerminan ekspresi diri secara arsitektur namun mengandung makna spiritual dari Dharma, ajaran Buddha untuk mengajak manusia mencapai tingkat tertinggi di luar kehidupan yang tidak kekal ini. Ini merupakan perwujudan dari salah satu ajaran Buddha yaitu tentang ketidakkekalan.

Akibat dari perubahan tersebut, melahirkan ekspresi dan variasi bebeda-beda baik aktivitas pradaksina maupun bangunan stupa. Keterkaitan antara keduanya hanya merupakan faktor fungsi tempat aktivitas membutuhkan wadah dan wadah berfungsi untuk menampung aktivitas. Namun hakikat akan makna yang terkandung pada pradaksina dan bangunan stupa tetaplah menggambarkan makna awal dari semua ekspresi tersebut. 


\section{DAFTAR PUSTAKA}

Ashihara, Yoshinobu. (1981). "Exterior Design in Architecture".New York: Van Nostrand Reihold Company.

Bandaranayake, Senake. (1974). "Sinhalese Monastic Architecture, Studies in South Asian Culture Volume IV"; Leiden:E.J Brill."Buddhist Worship". 1988. Srilanka: Buddhist Worship

Ching, Francis D.K. (1996). "Arsitektur, Bentuk, Ruang dan Susunannya". Jakarta: Erlangga.

Diputhera, Oka. (1979). "Maha Parinibbana Sutta". Jakarta: Proyek Pengadaan Kitab Suci Buddha.

Fisher, Robert. E. (1993). "Buddhist, Art, and Architecture". London: Thames and Hudson Ltd..

Kandahjaya, Hudaya. (1995). "The Master Key for Reading Borobudur Simbolism". Bandung: Karaniya.

Kusumah, Dharma. (1987). "Makna Candi Bharabudur-Mendut dalam agama Buddha". Jakarta: Universitas Krisnadwipayana.

Mangunwijaya, Y.B. (1988). "Wastu Citra”. Jakarta: PT. Gramedia.

Rahardjo. P. Mauro. (1999).“Diktat kuliah Perkembangan Arsitektur I”. Bandung: Unika Parahyangan

Sangha Mahayana Indonesia. (1991). "Kriteria Rumah Ibadah Umat Buddha Mahayana Indonesia, Cetakan I".Jakarta: Majelis Agama Buddha Indonesia

Subalaratano, Uttamo; "Puja"; Sangha Theravada Indonesia.Tim Penyusun. (1998). "Buku Pelajaran Agama Buddha Sekolah Menengah Tingkat Atas Kelas I".Surabaya:Paramita.

Wright, Frank Llyod. (1992). "Beetween Principle and Form". New York: Van Nostrand Reinhold. 